\title{
David Oliver: Older doctors revisited
}

\author{
David Oliver consultant in geriatrics and acute general medicine
}

Berkshire

I've never had a response to a column quite like that to Keeping Older Doctors in the Job. ${ }^{1}$ As well as several public rapid responses, including an inspirational paean to rural general practice from Dr James Douglas, ${ }^{2}$ I received over 100 private emails. I calculate the median respondent's age as 68 . Others replied on Twitter to \#olderdoctors.

My respondents weren't a scientifically constructed sample, and they may show self selecting response bias. Surgeons, GPs, anaesthetists, and then psychiatrists accounted for eight in 10 . I've picked out some key themes and anonymised the findings. Around one in five who had retired felt liberated and grateful, not resentful or regretful. Retired GPs, in particular, had generally had enough. Given the rapid increase in workload with no increase in resource, ${ }^{3}$ I can't blame them. GPs now report 60-plus patient contacts daily. ${ }^{4}$ Several mentioned the increasing age and medical complexity of patients, greater public expectations, and the challenges these posed.

Others had been pleased to leave while they had "still got it" and "before someone had to tell me." Anaesthetists, in particular, worried about going "over the hill," especially for urgent on-call work, but elective sessional lists and outpatient work seemed popular.

Several had found rewarding roles after medicine-as magistrates, healthcare consultants, or non-executives, or in education. One founded a medical school overseas in his late 60 s. Overall, around three in five respondents had worked beyond their mid-60s, and another one in five regretted not being able to.

Surgeons were consistently the most gung-ho about continuing, especially minus urgent on-call work. There was a sense of old-style professional control in the operating theatre and the opportunity for sessions in the private sector.

Around three in five respondents had worked beyond their mid-60s, and another one in five regretted not being able to

I found some consistent messages from those who hadn't embraced retirement and had left reluctantly. Firstly, they would be happy to stay on if roles were adapted to suit age and stamina levels and if part time working were made easier.

Secondly, most still greatly enjoyed the pure practice of medicine and patient contact (despite reported physician burnout being common, partly from a depersonalising and distancing from patients' problems). ${ }^{5}$ Yet they thought that the burdens of bureaucracy, organisational upheaval, and growing general management had undermined the professional and clinical autonomy that had defined them.

Thirdly, the perceived excessive administrative burden of revalidation, ${ }^{6}$ irritation at having to measure and justify work after years of trouble-free service, and a lack of willing responsible officers to oversee this, made staying on the medical register too off-putting for many respondents to stay in practice. Should we do more to tackle these issues? Recruitment and retention crises in medicine mean that experienced help should be encouraged and enabled. ${ }^{6-8}$ But then, so should a well earned retirement.

Competing interests: See www.bmj.com/about-bmj/freelancecontributors/david-oliver.

Provenance and peer review: Commissioned; not externally peer reviewed.

Follow David on Twitter, @mancunianmedic

Oliver D. David Oliver: Keeping older doctors in the job. BMJ 2016;356:i6260. doi:10. 1136/bmj.i6260 pmid:27884815.

2 Electronic responses. Keeping older doctors in the job. BMJ 2016. www.bmj.com/content/ 355/bmj.i6260/rapid-responses.

3 Baird B, Charles A, Honeyman M, Maguire D, Das P; King's Fund. Understanding the pressures in general practice. 5 May 2016. https://www.kingsfund.org.uk/publications/ pressures-in-general-practice.

4 Dayan M, Arora S, Rosen R, Curry N; Nuffield Trust. Is general practice in crisis? 4 Nov 2014. www.nuffieldtrust.org.uk/publications/general-practice-crisis.

5 Peckham C. Physician burnout: it just keeps getting worse. Medscape 2015 Jan 26. www. medscape.com/viewarticle/838437.

6 General Medical Council. What impact is revalidation having? 11 May 2016. www.gmcuk.org/publications/29146.asp.

7 Royal College of Physicians of London. Underdoctored, underfunded, overstretched: the NHS in 2016. 21 Sep 2016. https://www.rcplondon.ac.uk/guidelines-policy/underfundedunderdoctored-overstretched-nhs-2016.

8 Royal College of Physicians of London. 2014-15 census (UK consultants and higher specialty trainees). 1 Feb 2016. https://www.rcplondon.ac.uk/projects/outputs/2014-15census-uk-consultants-and-higher-specialty-trainees. 
Published by the BMJ Publishing Group Limited. For permission to use (where not already granted under a licence) please go to http://group.bmj.com/group/rights-licensing/

permissions 